\title{
MUSIK BIA: FUNGSI DAN REALITAS SOSIAL PADA MASYARAKAT DI KABUPATEN MINAHASA UTARA
}

\author{
Richard Junior Kapoyos \\ Prodi Musik Gereja, Sekolah Tinggi Thelogia Abdiel \\ Jl. Pangeran Diponegoro No.233, Ungaran, Kabupaten Semarang, Jawa Tengah 50511 \\ richardkapojos@gmail.com
}

\begin{abstract}
The Phenomenon of Bia Music in Batu village community needs to be closely examined considering that the Bia Music in the past to the present time is shifting and changing, due to lack of awareness, people's behavior towards Mia Music. The music of this tradition is very apprehensive to see the reality of the players from year to year diminishing in quantity and quality. The purpose of this research is to analyze: (1) Function of Bia Music, (2) Social reality that happened in society. This research uses qualitative method with data collection technique of interview, observation and document study. The technique of data validity is based on the credibility criteria, using triangulation of data. Data analysis techniques used are data collection, data presentation, data reduction, and data verification. The results of this study indicate that the Functions of Bia Music, among others, as a medium of ritual, communication media, into evangelism media, events of cultural festivals, education, association, entertainment and publicity. There are three moments of dialectics in the social realities of externalization, objectivity, and internalization.
\end{abstract}

Keywords: Functions of Bia Music; Social Reality and Culture

\section{Pendahuluan}

Kebudayaan bersifat dinamis, artinya selalu terjadi perubahan bentuk kebudayaan itu sendiri, entah itu perubahan minor atau perubahan mayor. Terdapat lima faktor yang menjadi penyebab perubahan kebudayaan yaitu: (1) Perubahan lingkungan alam; (2) Perubahan yang disebabkan adanya kontak dengan suatu kelompok lain; (3) Perubahan karena adanya penemuan (discovery); (4) Perubahan yang terjadi karena suatu masyarakat atau bangsa mengadopsi beberapa elemen kebudayaan material yang telah dikembangkan oleh bangsa lain di tempat lain; dan (5) Perubahan yang terjadi karena suatu bangsa memodifikasi cara hidupnya dengan mengadopsi suatu pengetahuan atau kepercayaan baru, atau karena perubahan dalam pandangan hidup dan konsepsinya tentang realitas (Settiadi, 2006, p. 44).

Kebudayaan merupakan produk dari seluruh rangkaian proses sosial yang dijalankan oleh manusia dalam masyarakat dengan segala aktivitasnya. Dengan demikian, maka kebudayaan adalah hasil nyata dari sebuah proses sosial yang dijalankan oleh manusia bersama masyarakatnya (Bungin, 2008, p. 52). Kebudayaan tidak terlepas dari kepribadian individu yang melalui suatu proses panjang. Manusia dalam kehidupannya 
sangat erat dengan kebudayaan selama jangka waktu hidupnya. Kebudayaan setiap daerah memiliki perbedaan sehingga setiap manusia masing-masing mempelajari kebudayaan yang ada di lingkungan masyarakatnya.

Kebudayaan sebagaimana dikemukakan oleh Bertrand (dikutip di Sulasman \& Gumilar, 2013, p. 18) merupakan "segala pandangan hidup yang dipelajari dan diperoleh oleh anggota-anggota suatu masyarakat". Kebudayaan pada tiap daerah itu berbeda sehingga masing-masing individu mempelajari kebudayaan yang ada di sekitar mereka. Setiap daerah memiliki kebudayaannya masing-masing yang bergantung pada kondisi masyarakat setempat. Berpijak dari adanya kebutuhan, kegiatan dan pandangan yang berbeda-beda dalam suatu kelompok masyarakat, maka setiap daerah memiliki kebudayaannya sendiri. Tidak terkecuali di Kabupaten Minahasa Utara yang memiliki ciri khas kebudayaan sendiri yang tidak dimiliki oleh daerah lain.

Pada tahun 1941 desa Batu masih dikenal dengan sebutan negeri batu onderdistrik tatelu dan pada tahun 1950 sebutan negeri batu diganti dengan nama Desa Batu Kecamatan Likupang Timur dan Likupang Barat. Musik Bia di desa Batu ini pada tahun 1941 adalah sebagai tanda bagi masyarakat dan pemerintah apabila ada pesawat penjajah (pada saat itu penjajahan jepang) menyerang desa-desa di sekitar desa Batu dan sebagai kode pada setiap dusun meniup bia/ kulit kerang dengan tidak henti-hentinya, terkecuali pesawat musuh tidak ada lagi. Pada tahun 1942 musik Bia ini dikumpulkan menjadi satu dan nadanya di stem oleh saudara Jefta Rare Rumimpunu (alm) dan Dusaw Lenzun (alm) yang merupakan penemu, pembuat sekaligus pelatih musik Bia pada era tahun 1942-an, akan tetapi Bapak Dusaw Lenzun meninggalkan desa Batu karena persaingan musik Biadan pindah ke Kairagi kota Manado. Pada saat ia berada di Kairagi, musik Bia sempat berkembang akan tetapi ketika ia meninggal dunia musik Bia di Kairagi punah karena tidak ada lagi penerus.

Sementara itu di desa Batu musik Bia tetap berkembang karena bapak Jefta Rare Rumimpunu terus mengembangkan musik tradisi di desa Batu. Kemudian bapak Jefta atau biasa dipanggil om Rare membuat satu kelompok musik Bia yang bernama mutiara. Bia/ keong — rumah kerang — adalah salah satu mahkluk hidup di laut. Waktu hidup bia ini diambil orang dengan cara menyelam, daging atau isinya dimakan dan kulitnya dibuang orang dipesisir pantai karena tidak berharga lagi. Desa Batu memiliki jarak yang jauh dari pantai kurang lebih $15 \mathrm{~km}$ dan dulunya orang desa berjalan kaki ke desa pesisir untuk jual beli atau tukar menukar untuk membeli ikan. Dengan itu pula ada beberapa orang mengambil kulit kerang (bia) lalu dibawa ke desa. 
Kulit kerang tersebut dilubangi, ditiup dan dibunyikan, kemudian dijadikan sebagai alat memanggil anggota masyarakat untuk mapalus atau biasa disebut bergotong royong. Awalnya dua sampai tiga orang meniup bia tersebut dan ternyata belum mempunyai nada yang baik dan belum teratur. Ada seorang yang berbakat dengan latar belakang pendidikan seni pada zaman penjajahan Belanda dan menamatkan sekolahnya di Vervoleg School tahun 1935 yaitu Jefta Rare Rumimpunu yang lahir pada tanggal 18 oktober 1921 dan meninggal pada bulan juni tahun 1978. Almarhum menciptakan nada dengan kalengkaleng susu kosong dan diletakkan pada tirisan atap, pada waktu hujan mulai turun air mulai menetes pada kaleng dan berdenting, disinilah almarhum memilih nada-nada dan mengetahui nada diatonik dengan mendegar bunyi. Pada tahun 1942 dibentuknya musik Bia pertama dengan beranggotakan 8 orang sesuai dengan tangga nada $\mathrm{F}$ satu oktaf yang lama kelamaan dibentuk sampai 16 orang dan terciptalah satu kelompok musik Bia. Dengan terciptanya musik Bia, waktu itu mereka dipanggil pemerintahan Jepang datang ke Tondano dengan jalan kaki karena dipaksa dan harus mengisi pertunjukan musik di acara pemerintahan Jepang dimasa itu. Dan pada akhirnya zaman musik ini punah sampai tahun 1968.

Pada bulan oktober tahun 1969 terbentuk pula generasi baru mencari alat musik baru dan tercipta lagi satu kelompok musik Bia baru yang dilatih oleh Yefta Rumimpunu (alm). Pada tahun 1970 musik ini dibawa ke Jakarta untuk dimainkan di senayan Jakarta. Kemudian pada tanggal 10 april 1975 musik Bia ini dibawa lagi oleh pemerintahan provinsi Sulawesi Utara ke Jakarta sebagai kontingen Sulawesi Utara untuk pembukaan taman miniatur indah. Sekitar tahun 1977-1983 nama musik Bia mutiara sudah tidak di dengar lagi (punah) kemudian pada tahun 1984 bapak Hermanus Rumuat Tooy (alm) dengan jabatan sebagai guru kesenian di desa Batu yang belajar kepada Doktor Lodewik Manik dan rekan-rekannya di Tomohon dan memperoleh sertifikat kesenian khusus membuat musik. Yang dulunya memakai nada $\mathrm{A}=$ Do sekarang memakai nada $\mathrm{C}=$ Do. Pada tahun 1998 musik mutiara terdaftar di kantor seni dan budaya di Kasuang Tomohon dibawah pimpinan bapak Bobby Sumendap. Musik Bia berjalan dengan aturan demi aturan sehingga pemimpin silih berganti. Pada tanggal 9 mei 2005 musik mutiara diundang ke Jakarta untuk mengikuti acara pembukaan Kain Pina Bia yang diikuti perusahaanperusahaan besar di Minahasa. Musik ini juga diundang dalam acara gereja asia, siding gereja reformasi sedunia, persatuan gereja Indonesia, acara perkawinan dan acara pemerintahan provinsi Sulawesi Utara. 
Pada tahun 2010 musik Bia mutiara terpecah menjadi 3 kelompok yang pertama musik Bia mutiara, yang kedua permata laut dan yang ketiga mutiara kasih. Kelompok musik Bia mutiara dan mutiara kasih dipimpin oleh bapak Robby Lengkong dan Yano Tooy anak dari bapak Hermanus Tooy. Kelompok musik Bia permata laut dipimpin oleh Bapak Hajai Zakawerus. Pada tahun 2011-2012 musik Bia di desa Batu sudah dapat mengikuti rekor muri dan rekor dunia di tompaso pinabetengan juga hadir dalam acara, pameran budaya nasional di Jakarta tahun 2011, acara dies natalis ke-71 fakultas ilmu pengetahuan budaya Universitas Indonesia (UI) forum budaya Minahasa dan festival Minahasa di Jakarta tahun 2011 dan acara festival Pinabetengan 2012.

Dalam mempelajari perubahan sosial pada masyarakat, perlu diketahui sebab-sebab yang melatarbelakangi terjadinya perubahan itu. Perubahan sosial merupakan gejala umum dalam masyarakat yang perlu didekati dengan model pemahaman yang lebih rinci dan khusus. Upaya tersebut untuk mendapatkan kejelasan subtansial sehingga berguna untuk memahami dinamika kehidupan masyarakat. Tujuan Penelitian ini untuk mengetahui, (1) bagaimana fungsi musik Bia pada masyarakat di Desa Batu Kecamatan Likupang Selatan Kabupaten Minahasa Utara Sulawesi Utara dan (2) bagaimana realitas sosial yang terjadi pada masyarakat di Desa Batu Kecamatan Likupang Selatan Kabupaten Minahasa Utara Sulawesi Utara.

\section{Metode Penelitian}

Metode yang digunakan dalam penelitian ini adalah metode penelitian kualitatif. Penelitian kualitatif adalah penelitian yang bersifat deskripsi, tidak menggunakan angkaangka, dan mendeskripsikan berupa ucapan, tulisan dan pengamatan. Pendekatan yang digunakan dalam penelitian ini, yaitu pendekatan interdisiplin dengan melibatkan disiplin ilmu etnomusikologi, sosiologi dan estetika. Etnomusikologi digunakan untuk menganalisis intraestetiknya, yaitu bentuk pertunjukan musik Bia. Sedangkan sosiologi untuk mengkaji ekstraestetiknya, yaitu merepresentasikan realitas sosial yang terjadi pada masyarakat di Desa Batu Kecamatan Likupang Selatan Kabupaten Minahasa Utara Provinsi Sulawesi Utara.

Desain penelitian dalam penelitian ini adalah studi kasus, yang berarti temuan dalam penelitian ini tidak berlaku untuk umum, tetapi hanya berlaku bagi karateristik atau fenomena yang sama. Artinya, kasus atau temuan penelitian ini hanya berlaku untuk masyarakat petani di Desa Batu. Lokasi penelitian yang dilaksanakan penulis berada di 
Desa Batu Kecamatan Likupang Selatan Kabupaten Minahasa Utara. Sasaran penelitian yang dikaji atau yang menjadi fokus dalam penelitian ini berkait dengan masalah yang dikemukakan oleh penulis, yaitu musik Bia di Desa Batu. Fokus penelitian ini mengkaji tentang fungsi musik Bia dan realitas sosial masarakat di Desa Batu, dengan objek material musik Bia.

Jenis data dalam penelitian ini adalah data kualitatif, sedangkan sumber data dalam penelitian ini dibedakan menjadi dua yaitu data primer dan data sekunder. Peneliti memperoleh sumber data dari sumber utama yaitu informan yang bertindak sebagai pelopor eksisnya musik Bia serta anggota masyarakat yang bertindak sebagai pelakupelaku utama musik Bia di Desa Batu Kecamatan Likupang Selatan Kabupaten Minahasa Utara. Data pendukung diperoleh dari observasi dan kepustakaan serta beberapa informan lainnya seperti seniman-seniman, tokoh masyarakat dan anggota masyarakat lainnya. Selain itu, penulis juga melakukan langkah-langkah untuk memperoleh data dari sumber data sekunder yaitu berupa data-data yang mendukung penelitian. Data sekunder adalah sumber data yang diperoleh secara tidak langsung, tetapi dapat membantu dan memberikan informasi pendukung sebagai bahan penelitian. Data-data tersebut meliputi dokumen atau catatan sejarah dan peristiwa, foto-foto kegiatan dan acara yang mendukung serta bukubuku yang berkaitan dengan penelitian.

Pengumpulan data dalam penelitian ini menggunakan teknik observasi, wawancara, dan studi dokumen. Dalam memperoleh data penelitian, penulis menggunakan observasi partisipan. Penulis mengamati sekaligus ikut serta dalam kegiatan-kegiatan yang dilakukan oleh subjek yang sedang diamati. Wawancara yang digunakan dalam penelitian ini adalah wawancara bebas terstruktur yaitu pewawancara membawa pedoman yang merupakan garis besar tentang hal yang akan diteliti. Alat-alat yang digunakan peneliti dalam melakukan kegiatan wawancara yaitu: (1) daftar pertanyaan; (2) buku catatan; (3) kamera (untuk foto dan hasil rekaman suara). Kemudian peneliti merangkum hasil wawancara yang telah dilakukan secara sistematis agar lebih mudah dimengerti. Wawancara dilakukan dengan seniman pelopor musik Bia di Desa Batu yaitu Bapak Robby Lengkong, Yano Tooy, dan Hajai Zakawerus, serta masyarakat sekitar dan juga penonton. Peneliti menggunakan metode studi dokumen dengan tujuan mengumpulkan data yang berguna untuk memperkuat data yang diperoleh dari wawancara. Dokumentasi digunakan untuk mengumpulkan dokumen berupa materi pembelajaran, media pembelajaran, foto-foto dan 
video pada saat proses pembelajaran. Dokumentasi juga digunakan untuk merekam kegiatan musik Bia di Desa Batu Kecamatan Likupang Selatan Kabupaten Minahasa Utara.

Dalam menganalisis data, metode yang digunakan yaitu analisis kualitatif. Diletakkan dalam kerangka berpikir yang menyeluruh dan sistemik. Data yang berupa kata kata, pernyataan-pernyataan ide, penjelasan-penjelasan ide atau kejadian dan bukan rangkaian angka, telah dikumpulkan dan diproses kemudian disusun dalam teks yang diperluas dan dianalisis. Bahwa analisis data merupakan kegiatan bersama dan saling menjalin antara langkah reduksi data, penyajian data dan pemeriksaan kesimpulan atau verifikasi.

\section{Fungsi Musik Bia}

Fungsi adalah sesuatu yang menunjukan kaitan antara satu hal dengan hal yang lain atau sesuatu yang menyatakan hubungan antara suatu hal dengan pemenuhan kebutuhan tertentu (Sedyawati, 1981). Mengenai fungsi seni pertunjukan Merriam (1964, p. 222-227) membagi menjadi sepuluh yaitu:1) emotional expression, 2) aesthetic enjoyment, 3) entertainment, 4) communication, 5) symbolic representation, 6) physical response, 7) enforcing conformity to social norms, 8) validation of social institution and religion, 9) contribution to the continuity and stability of culture, 10) contribution to the intregation of society.

Fungsi musik Bia sebelum mengalami perubahan adalah sebagai media pengumpul massa, sebagai media ritual dan sebagai media pengiring tari. Sejak zaman pra sejarah beragam alat musik bia berperan penting dalam menyampaikan pesan, karena diketahui ada sejumlah jenis bia dapat mengeluarkan nada yang bervariasi dan relatif nyaring terdengar. Ketika itu, pesan atau pertanda yang diperdengarkan kepada masyarakat memiliki perbedaan nada. Tentu perbedaan itu didasarkan pada maksud pesan yang disampaikan, seperti untuk memanggil orang berkumpul tentunya memiliki perbedaan lantunan bila hendak memerintakan prajurit siap siaga.

Selain itu tujuan dan nada suara yang diperdengarkan bisa berbeda-beda di setiap wilayah atau suku, yang pasti penggunaan bia sebagai alat pemberi pesan sangatlah membantu warga atau suku tertentu diberbagai penjuru dunia dalam penyampaian atau penerimaan pesan atau tanda. Seperti memanggil warga untuk berkumpul, mengikuti pesta, membuka suatu kegiatan rapat atau musyawarah suatu suku, pembukaan suatu kegiatan olahraga, meminta prajurit siap berperang atau menghadiri upacara, bahkan alat musik bia 
sering dibunyikan oleh pasukan kerajaan sebagai tanda kemenangan atau ketika usai berperang (Wenas, 2000, p. 20).

Dengan kegiatan sehari-hari, alat musik bia dijadikan tanda harian untuk memulai aktivitas atau memulai pekerjaan di kalangan masyarakat umum di desa-desa, adanya penjualan ikan di pasar desa, bahkan tanda untuk berdoa, tanda adanya aktivitas pelayaran, berlabuh atau tanda adanya kabut tebal di laut. Selain itu alat musik bia juga digunakan sebagai tanda bahaya adanya serangan musuh, serangan binatang buas bahkan adanya bencana alam, pemberian tanda tentang adanya petinggi warga atau suku yang meninggal, adanya penyambutan tamu penting terutama pejabat yang sedang berkunjung.

Fungsi musik Bia setelah perubahan terjadi pada tahun 1942-1994 dan ditahun 1995 sampai sekarang. Tahun 1942-1994 musik Bia menjadi media hiburan dan media pengiring pengantin dalam pernikahan. Sedangkan musik Bia pada tahun 1995 sampai dengan sekarang musik Bia itu menjadi media pendidikan, publikasi, pergaulan, hiburan, untuk event-event festival kebudayaan dan sebagai media penginjilan.

Di dalam melaksanakan setiap aktivitas baik formal atau non formal seperti acara perkawinan, upacara-upacara keagamaan, dan lain-lain yang bersifat sosial, kelompok musik Bia selalu tampil dalam pertunjukan. Kehadiran musik Bia sangat penting bagi masyarakat di desa Batu untuk menyemarakkan suasana perayaan seperti hari besar Nasional dan hari besar lainnya. Hal ini dirasakan sangat penting, mengingat seperti yang diutarakan oleh masyarakat desa Batu pada umumnya, jika keberadaan musik Bia tidak ada dalam pertunjukan rakyat tersebut, suasana terasa kurang menarik. Selain sebagai identitas budaya yang selalu ditampilkan dalam penyambutan tamu, baik dari dalam maupun dari luar daerah, musik Bia dalam perannya turut menghibur masyarakat yang ikut hadir dalam setiap kegiatan yang dilaksanakan.

Sebuah kesenian akan berfungsi dan berkembang di tengah kehidupan masyarakatnya apabila masih dibutuhkan oleh masyarakat setempat dimana kesenian itu berada. Di desa Batu keberadaan kesenian musik Bia tetap berfungsi dalam kehidupan masyarakat, sebagai salah satu musik hiburan dalam berbagai acara yang dilaksanakan ditengah masyarakat. Dalam hal ini Soedarsono (1985) mengemukakan bahwa "seni budaya sebagai ekspresi perasaan manusia merupakan kebutuhan yang berkembang sesuai dengan perkembangan kehidupan masyarakat dan lingkungan” (p. 17).

Keberadaan musik Bia sampai sekarang masih tetap bertahan dalam masyarakat, karena ditopang oleh tradisi masyarakat yang selalu menampilkan musik Bia sebagai 
penyemarak/ pelengkap dalam setiap acara seperti iring-iringan pengantin pernikahan, memperingati hari besar Nasional tanggal 17 agustus dan hari-hari besar lainnya, kegiatan keagamaan, dan jenis kegiatan lainnya baik di dalam daerah maupun di luar daerah, serta event-event yang lain. Artinya fungsi musik Bia ini telah mengalami perubahan. Perubahan tersebut diakibatkan oleh karena berubahnya pola masyarakat sehingga kesenian juga ikut berubah, karena masyarakat dengan budaya atau keseniannya tidak dapat dipisahkan. Sejalan dengan itu Kayam (1981) menjelaskan bahwa seni adalah ungkapan kreativitas dari kebudayaan yang tidak pernah lepas dari masyarakatnya (p. 37-38).

\section{Realitas Sosial}

Istilah konstruksi atas realitas sosial (social construction of reality) menjadi terkenal sejak diperkenalkan oleh Peter L. Berger \& Thomas Luckman (1966) melalui bukunya yang berjudul The Social Construction of Reality: A Treatise in the Sociological of Knowledge. Ia menggambarkan proses sosial melalui tindakan dan interaksinya, dimana individu menciptakan secara terus menerus suatu realitas yang dimiliki dan dialami bersama secara subjektif.

Dua istilah dalam sosiologi pengetahuan Berger adalah kenyataan dan pengetahuan. Berger \& Luckmann (1990, p. 1) mulai menjelaskan realitas sosial dengan memisahkan pemahaman kenyataan dan pengetahuan. Realitas diartikan sebagai suatu kualitas yang terdapat didalam realitas-realitas yang diakui sebagai memiliki keberadaan (being) yang tidak tergantung pada kehendak kita sendiri, sedangkan pengetahuan diartikan sebagai kepastian bahwa realitas-realitas itu nyata (real) dan memiliki karakteristik yang spesifik.

Menurut Berger \& Luckmann (dikutip di Polomo, 2010, p. 301) terdapat dua objek pokok realitas yang berkenaan dengan pengetahuan yakni realitas subjektif dan realitas objektif. Realitas subjektif berupa pengetahuan individu, disamping itu realitas subjektif merupakan konstruksi definisi realitas yang dimiliki individu dan dikonstruksi melalui proses internalisasi. Realitas subjektif yang dimiliki masing-masing individu merupakan basis untuk melibatkan diri dalam proses eksternalisasi, atau proses interaksi sosial dengan individu lain dalam sebuah struktur sosial. Melalui proses eksternalisasi itulah individu secara kolektif berkemampuan melakukan objektivikasi dan memunculkan sebuah konstruksi realitas objektif yang baru. Sedangkan realitas obojektif dimaknai sebagai fakta sosial. Selain itu, realitas objektif merupakan suatu kompleksitas definisi realitas serta 
rutinitas tindakan dan tingkah laku yang telah mapan terpola, yang kesemuanya dihayati oleh individu secara umum sebagai fakta.

Berger \& Luckmann (dikutip di Bungin, 2008, p. 14) mengatakan bahwa institusi masyarakat tercipta dan dipertahankan atau diubah melalui tindakan dan interaksi manusia. Meskipun institusi sosial dan masyarakat terlihat nyata secara objektif, namun pada kenyataan semuanya dibangun dalam definisi subjektif melalui proses interaksi. Objektivitas baru bisa terjadi melalui penegasan berulang-ulang yang diberikan oleh orang lain yang memiliki definisi subjektif yang sama. Pada tingkat generalitas yang paling tinggi, manusia menciptakan dunia dalam makna simbolis yang universal yaitu pandangan hidupnya yang menyeluruh, yang memberi legitimasi dan mengatur bentuk-bentuk sosial serta memberi makna pada berbagai bidang kehidupan. Berger \& Luckman mengatakan terjadi dialektika antara individu menciptakan masyarakat dan masyarakat menciptakan individu. Proses dialektis tersebut mempunyai tiga tahapan, Berger menyebutnya sebagai momen, ada tiga tahap peristiwa yaitu eksternalisasi, objektivasi, dan internalisasi.

Teori konstruksi sosial dalam gagasan Berger mengandaikan bahwa agama sebagai bagian dari kebudayaan, merupakan konstruksi manusia, artinya terdapat proses dialektika ketika melihat hubungan masyarakat dengan agama, bahwa agama merupakan entitas yang objektif karena berada diluar diri manusia. Dengan demikian agama mengalami proses objektivasi, seperti ketika agama berada didalam teks atau menjadi tata nilai, norma, aturan dan lain sebagainya. Teks atau norma tersebut kemudian mengalami proses internalisasi kedalam diri individu, dikarenakan agama telah diinterpretasikan oleh masyarakat untuk menjadi pedomannya. Agama juga mengalami proses eksternalisasi karena ia menjadi acuan norma dan tata nilai yang berfungsi menuntun dan mengontrol tindakan masyarakat (Berger \& Luckmann, 1990, p. 33).

Ketika masyarakat dipandang sebagai sebuah kenyataan ganda, objektif dan subjektif maka ia berproses melalui tiga momen dialektis, yakni eksternalisasi, objektivasi, dan internalisasi. Dengan demikian, bisa dipahami bahwa realitas sosial merupakan hasil dari sebuah konstruksi sosial karena diciptakan oleh manusia itu sendiri. Masyarakat yang hidup dalam konteks sosial tertentu, melakukan proses interaksi secara simultan dengan lingkungannya. Dengan proses interaksi, masyarakat memiliki dimensi kenyataan sosial ganda yang bisa saling membangun, namun sebaliknya juga bisa saling meruntuhkan. Masyarakat hidup dalam dimensi-dimensi dan realitas objektif yang dikonstruksi melalui momen eksternalisasi dan objektivasi, dan dimensi subjektif yang dibangun melalui 
momen internalisasi. Momen eksternalisasi, objektivasi, dan internalisasi tersebut akan selalu berproses.

\section{Eksternalisasi}

Proses sosial momen eksternalisasi kaitannya dengan musik Bia bahwasannya dalam proses transformasi dari bia bintuang, bia susu dan bia tandu hingga bisa menjadi suatu alat musik yang saat ini dikenal dengan istilah musik Bia, didalamnya terdapat momen eksternalisasi dimana terjadi proses pengeluaran gagasan dari dunia ide ke dunia nyata. Proses tersebut terpresentasikan dari proses terciptanya alat musik Bia, dimana alat musik ini mulanya berasal dari Bia atau Rumah Keong/ siput Laut. Bia pada zaman dahulu biasa digunakan oleh masyarakat petani sebagai media komunikasi memanggil masyarakat untuk berkumpul dan melakukan mapalus atau kerja bakti/ gotong royong (wawancara, Yano Tooy 2017).

\section{Objektivasi}

Momen objektivasi yang terjadi dalam kaitannya dengan musik Bia, dimana instrumen Bia sebagai imitasi dari musik bambu mengalami proses habituasi/ pembiasaan terhadap norma dan budaya yang berkembang di masyarakat. Musik Bia berkembang menjadi salah satu kesenian kerakyatan yang populer. Hal ini didasari karena Bia merupakan hasil alam yang di dapat dari laut. Bahan baku pembuatan Bia banyak tersedia dan mudah di dapatkan oleh masyarakat karena letaknya dipesisir pantai. Fungsi musik Bia sebagai media ritual, media komunikasi, sedangkan fungsi pertunjukan musik Bia yaitu sebagai media penginjilan, event-event festival kebudayaan, pendidikan, pergaulan, hiburan, dan publikasi.

Pada momen objektivasi ini, para pencipta musik Bia berasumsi jika alat musik ini merupakan imitasi dari suara musikal musik bambu. Fungsi utama bundengan pada periodisasinya digunakan sebagai sarana Ritual dan Komunikasi. Penggunaan musik Bia yang memiliki irama dan suara yang menyerupai musik bambu, dengan irama yang monoton diyakini bisa membantu untuk berkonsentrasi dalam ritual keagamaan. Penggunaan musik Bia sebagai sarana beribadah maupun mengisi waktu senggang dilakukan secara terus menerus sehingga mengalami proses habituasi atau pembiasaan 
yang pada akhirnya menjadi pola yang direproduksi dan dipahami oleh para seniman musik Bia hingga saat ini (Wawancara, Hajai Zakawerus 2017).

\section{Internalisasi}

Momen internalisasi yang terjadi pada masyarakat mengenai musik Bia adalah dengan dijadikannya musik Bia sebagai identitas Provinsi Sulawesi Utara khususnya di Desa Batu Kecamatan Likupang Selatan Kabupaten Minahasa Utara. Pada tahun 2010 musik Bia mutiara terpecah menjadi 3 kelompok, yang pertama musik Bia mutiara, yang kedua permata laut dan yang ketiga mutiara kasih. Kelompok musik Bia mutiara dan mutiara kasih dipimpin oleh bapak Robby Lengkong dan Yano Tooy anak dari bapak Hermanus Tooy. Kelompok musik Bia permata laut dipimpin oleh Bapak Hajai Zakawerus. Pada tahun 2011-2012 musik Bia di desa Batu sudah dapat mengikuti rekor muri dan rekor dunia di Tompaso Pinabetengan yang juga hadir dalam acara pameran budaya Nasional di Jakarta tahun 2011, acara dies natalis ke-71 fakultas ilmu pengetahuan budaya Universitas Indonesia (UI) forum budaya Minahasa dan festival Minahasa di Jakarta tahun 2011 dan acara festival Pinabetengan 2012 (wawancara, Robby Lengkong 2017).

\section{Kesimpulan}

Pada hakikatnya kehidupan dan perkembangan seni berhubungan erat dengan keadaan lingkungan masyarakat. Seni selalu berkembang seiring dengan perkembangan pola pikir masyarakat setempat, sehingga faktor lingkungan sangat berpengaruh dalam pembentukan seni. Berdasarkan hasil penelitian dapat dikatakan bahwa fungsi musik Bia adalah sebagai media ritual, komunikasi, penginjilan, event-event festival kebudayaan, pendidikan, pergaulan, hiburan, dan publikasi. Sedangkan realitas sosial terdiri dari tiga momen dialektika yaitu eksternalisasi, objektivasi, dan internalisasi.

\section{Kepustakaan}

Berger, Peter L., \& Luckmann, Thomas. (1990). Tafsir Sosial Atas Kenyataan. Jakarta: LP3ES.

Bungin, Burhan. (2008). Sosiologi Komunikasi: Teori, Paradigma, dan Diskursus Teknologi Masyarakat. Jakarta: Kencana. 
(2008). Konstruksi Sosial Media Massa: Kekuatan Pengaruh Media Massa, Iklan, Televisi, dan Keputusan Konsumen Serta Kritik Terhadap Peter L. Berger \& Thomas Luckmann. Jakarta: Kencana Prenada Media Grup.

Kayam, Umar. (1981). Seni tradisi, masyarakat. Jakarta: sinar harapan.

Merriam, P. Allan. (1964). The anthropology of music. Illionis: North-western university press.

Polomo, Margaret M. (2010). Sosiologi Kontemporer. Jakarta: Rajawali Press.

Sedyawati, Edi. (1981). Perubahan seni pertunjukan. Jakarta: sinar harapan.

Settiadi, Elly M, dkk. (2006). Ilmu Sosial dan Budaya Dasar. Jakarta: Kencana Prenada Media Grup.

Soedarsono. (1985). Peranan seni budaya dalam sejarah kehidupan manusia kontinuitas dan perubahannya. Dalam pidato pengukuhan jabatan guru besar pada fakultas sastra UGM. Yogyakarta: Universitas Gajah Mada.

Sulasman \& Gumilar, Setia. (2013). Teori-Teori Kebudayaan. Bandung: Pustaka Setya.

Wenas, Yessy. (2000). Sembilan seni tradisi disulawesi utara. Manado: Institut Budaya Sulawesi Utara. 